\title{
Seropositivity of Delta Hepatitis in HBsAg Positive Patients in Eskișehir Province
}

\author{
Eskișehir lli'nde HBsAg Pozitif Kișilerde Delta Hepatit Seropozitifliği
}

\author{
Pınar KORKMAZ, Nevil AYKIN, Figen ÇAĞLAN ÇEVIK, Hakkı Mustafa GÜLDÜREN, Yeşim ALPAY
}

Yunus Emre State Hospital, Infectious Diseases and Clinical Microbiology Clinic, Eskişehir, Turkey

\begin{abstract}
Objective: In this study, it was aimed to determine positivity of anti-HDV in inactive HBsAg carriers and the patients diagnosed with chronic hepatitis B in our province. Materials and Methods: We retrospectively evaluated the data of a total of 547 HBsAg-positive patients (204 chronic hepatitis B patients and 343 inactive HBsAg carriers) who were admitted to the infectious disease outpatient clinic in our hospital between July 2012 and October 2013

Results: Three hundred and eight (56.3\%) patients were males and 239 (43.7\%) were females. The mean age of the subjects was $48.52 \pm 12.38$ years. Anti-HDV positivity was determined in $5(0.9 \%)$ of the $547 \mathrm{HBsAg}$-positive patients (204 chronic hepatitis B patients and 343 inactive HBsAg carriers). HDV-RNA positivity was determined in all anti-HDV-positive patients. While anti-HDV positivity was determined in $3(0.87 \%)$ of 343 inactive HBsAg carriers, $2(1 \%)$ of 204 chronic hepatitis B patients were found to be anti-HDV-positive.

Conclusion: In conclusion, anti-HDV positivity determined in chronic hepatitis $\mathrm{B}$ patients and inactive $\mathrm{HBsAg}$ carriers in our province decreased within years consistently in accordance with all regions of our country. (Viral Hepatitis Journal 2014; 20(2): 72-74)
\end{abstract}

Key words: $H D V$, chronic hepatitis B, inactive HBsAg carrier
ÖZET

Amaç: Bu çalışmada ilimizdeki inaktif $\mathrm{HBsAg}$ taşıyıcılarında ve kronik hepatit B tanısı alan hastalarda anti-HDV pozitifliğinin saptanması amaçlandı.

Gereç ve Yöntemler: Temmuz 2012-Ekim 2013 tarihleri arasinda hastanemiz Enfeksiyon Hastalıkları polikliniğine başvuran 204'ü kronik hepatit B, 343'ü inaktif hepatit B taşıyıııI olan 547 HBsAg pozitif bireyin dosyası retrospektif olarak incelendi.

Bulgular: Hastaların 308'i $(\% 56,3)$ erkek, 239 'u $(\% 43,7)$ kadın olup, yaş ortalaması 48,52+12,38 idi. Çalışmamızda 204'ü kronik HBV, 343'ü inaktif HBV taşıyııısı olan $547 \mathrm{HBsAg}$ pozitif kişinin 5'inde $(\% 0,9)$ Anti -HDV pozitifliği saptandı. Anti-HDV pozitif hastaların hepsinde HDV RNA pozitif idi. Üçyüz kırküç inaktif HBV taşııııısııın 3'ünde $(\% 0,87)$ Anti-HDV pozitifliği saptanırken, 204 kronik hepatit B hastasının 2 'sinde (\%1) Anti-HDV pozitif idi.

Sonuç: Sonuç olarak, ilimizde KHB'li hastalarımızda ve inaktif hepatit B taşıyıcılarımızda elde edilen anti-HDV pozitifliği, ülkemiz geneliyle uyumlu olarak yıllar içerisinde azalma göstermiştir. (Viral Hepatit Dergisi 2014; 20(2): 72-74) Anahtar Kelimeler: HDV, kronik hepatit B, inaktif HBsAg taşıyıcıII

\section{Introduction}

Viral hepatitis remain a significant public health issue throughout the world including our country (1). Hepatitis B virus (HBV) infection is a common and severe inflammatory disease of the liver with a wide clinical spectrum from asymptomatic carrier state to chronic hepatitis and fulminant hepatitis (2). Hepatitis D virus (HDV) is a defective virus which may cause disease only in individuals with HBV infection (3). Worldwide, approximately more than 15 million HBV carriers are infected with HDV. Our country is located in an intermediate endemic area for HDV $(4,5)$.

When the studies performed regarding hepatitis delta in our country are evaluated, it is observed that anti-HDV positivity is present at a rate of $20 \%$ in patients with chronic hepatitis and at a rate of $4.9 \%$ in inactive hepatitis $B$ carriers (6).

In this study, it was aimed to determine anti-HDV positivity in inactive hepatitis $B$ carriers and chronic hepatitis $B(C H B)$ patients in our hospital and to provide contribution to the data on the seroprevalence of hepatitis delta in our province.

\section{Material and Methods}

We retrospectively evaluated the hospital records of 547 HBsAg-positive patients who were admitted to the infectious disease outpatient clinic between July 2012 and October 2013. According to the American Association for the Study of Liver 
Diseases (AASLD) 2009 Practise Guidelines, 204 of our patients were with $\mathrm{CHB}$ and 343 of them were inactive HBsAg carriers. Anti-HDV was studied using ELISA (DIA.PRO, Italy), ELX 50 bioelisa washer and ELX 800 bioelisa reader. HDV RNA extraction from plasma or serum samples of the patients was performed automatically in EZ1 Advanced (QIAGEN, Germany) device using EZ1 Virus Mini Kit v2.0 (QIAGEN, Germany). HDV RNA amount (viral load) was studied in Real-Time PCR device (ROTOR GENE 6000, CORBETT Research Pty Ltd, Austria) according to the recommendations of the manufacturer.

\section{Results}

Three hundred and eight (56.3\%) of the patients were males and $239(43.7 \%)$ were females. The mean age was $48.52 \pm 12.38$ years. Anti-HDV positivity was determined in $5(0.9 \%)$ of the 547 HBsAg-positive patients (204 CHB patients and 343 inactive HBsAg carrier). HDV-RNA positivity was determined in all antiHDV-positive patients. While anti-HDV positivity was determined in $3(0.87 \%)$ of 343 inactive HBsAg carriers, $2(1 \%)$ of $204 \mathrm{CHB}$ patients were found to be anti-HDV-positive.

\section{Discussion}

While the prevalence of HDV infection is less than HBV infection, the clinical feature caused by HDV infection is severe (7). HDV infection is a critical problem in our country, particularly in Eastern and Southeastern Anatolia. In recent years, HDV infection is decreasing throughout the country, however, the positivity rate still remains to be critical (6). In a study performed in Ankara between 2009 and 2011, Altınbas et al. reported that anti-HDV positivity rate was $2 \%$ in $348 \mathrm{HBsAg}$-positive patients (8). AntiHDV positivity was determined at a rate of $2 \%$ in $913 \mathrm{HBsAg}$ positive patients in a study performed by Yurtsever et al. in Izmir between 2008 and 2010, at a rate of 9.7\% in 787 HBsAg-positive patients in a study performed by Dogan et al. in Ağrı between 2009 and 2012, at a rate of 2.5\% in $194 \mathrm{HBsAg-positive} \mathrm{patients}$ in a study performed by Sırmatel et al. in Şanlıurfa between 2004 and 2006, at a rate of $7.1 \%$ in $8959 \mathrm{HBsAg}$-positive patients in a study performed by Azap et al. in Ankara between 1987 and 2003 , and at a rate of $7 \%$ in 3753 HBsAg-positive patients in a study performed by Yaşar K et al. in Istanbul between 2009-2010 (2,9-12).

Anti-delta IgG positivity was determined at a rate of $2.7 \%$ in a nationwide community-based survey on the prevalence of viral hepatitis in our country $(13,14)$. In our study, anti-HDV positivity was determined in $5(0.9 \%)$ of the $547 \mathrm{HBsAg}$-positive patients in Eskisehir province. When the data of our province was evaluated, it was seen that anti-HDV positivity was lower than general average of our country. This was attributed to intensity of anti-HDV positivity especially in the East and Southeast regions of our Turkey and lower rates of anti-HDV positivity reported in the Central Anatolia Region including also our province.

Anti-delta positivity can vary in different patient groups. In a meta-analysis performed by Degertekin et al. in our country, antiHDV positivity rate in inactive hepatitis B carriers between 1980 and 2005 was determined to be $4.9 \%$. In the same study, it was reported that this rate decreased to $2.9 \%$ after 2001 (6). Anti-HDV positivity in inactive hepatitis B carriers was determined to be $6.3 \%$ in Izmir by Yurtsever et al., $2.7 \%$ in Afyon by Demirdal et al., $5.4 \%$ in Ankara by Balik et al., $1.4 \%$ in Adıyaman by Kölgelier et al., and $3.6 \%$ in Trabzon by Kaya et al. $(9,15-18)$. In a study performed by Us et al. in Eskişehir province between 1995 and 1997, anti-HDV positivity in 50 inactive hepatitis B carriers was determined to be $2 \%$ (19). In our study, this rate was determined to be $0.87 \%$ and it was observed that seroprevalence of hepatitis delta in inactive hepatitis B carriers decreased within years in our region.

Frequency of HDV infection in patients with $\mathrm{CHB}$ was determined to be $24.8 \%$ in 145 patients by Guducuoglu et al. in Van, $45.5 \%$ in 282 patients by Bahcecioglu et al. in Elazığ, $27.5 \%$ in 120 patients by Celen et al. in Diyarbakır, $2.9 \%$ in 69 patients by Demirdal et al. in Afyon, 3.3\% in 30 patients by Kaya et al. in Trabzon, 8.9\% in 112 patients by Kolgelier et al. in Adiyaman, and $6.3 \%$ in 645 patients by Yurtsever et al. in Izmir $(9,15,17,18,20-22)$.

In their study, Degertekin et al. demonstrated that while the rate of anti-HDV positivity in patients with CHB in our country was $31 \%$ between 1980 and 1990, it regressed to 19.4\% between 1991 and 2000 and to $11 \%$ between 2001 and 2005. The difference was considered to be statistically significant $(p<0.001)(6)$. In a study performed in Eskişehir province between 1995 and 1997, Us et al. determined HDV infection in $12(15.58 \%)$ of 77 patients with $\mathrm{CHB}$ (19). In our study, anti-HDV positivity was determined in $2(1 \%)$ of 204 patients with chronic hepatitis B. A decrease was determined in seroprevalence of HDV infection in patients with $\mathrm{CHB}$ in our province within years consistently in accordance with all regions of our country.

In conclusion, anti-HDV positivity determined in CHB patients and inactive HBsAg carriers decreased within years in Eskişehir province. However, our country is located in an intermediate endemic area for HDV and regional data may change due to immigrations, therefore, the presence of hepatitis $D$ infection must be definitely investigated in HBsAg carriers.

\section{Conflict of interest: None declared.}

\section{References}

1. Khokhar N, Gill ML, Malik GJ. General seroprevalence of hepatitis $\mathrm{C}$ and hepatitis $\mathrm{B}$ virus infections in population. J Coll Physicians Surg Pak. 2004; 14(9): 534-6.

2. Yaşar Kart K, Pehlivanoğlu F, Şengöz G. Sekiz aylık dönemde laboratuvarımızda saptanan Hepatit B ve Hepatit D seroprevalansı. Viral Hepatit Dergisi. 2011; 17(1): 22-6.

3. Sonsuz A. Kronik hepatit B ve Delta. I.Ü. Cerrahpaşa Tıp Fakültesi Sürekli Tıp Eğitimi Etkinlikleri, Hepato-Bilier Sistem ve Pankreas Hastalıkları Sempozyumu dizisi. 2002: 67-8.

4. Hughes SA, Wedemeyer H, Harrison PM. Hepatitis delta virus Lancet. 2011; 378(9785): 73-85.

5. Mıstık R. Türkiye'de viral hepatit epidemiyolojisi - Yayınların irdelenmesi. Tabak F, Balık I, Tekeli E. (editörler). Viral Hepatit; 2007: 9-50.

6. Değertekin $\mathrm{H}$, Yalçın K, Yakut $\mathrm{M}$. The prevalance of hepatitis delta virus infection in acute and chronic liver diseases in Turkey: An analysis of clinical studies. Turk J Gastroenterol. 2006; 17(1): 25-34. 
7. Tosun S. Hepatit Delta Virüs Enfeksiyonu Epidemiyolojisinde Değişim ve Ülkemizdeki Güncel Durum. Viral Hepatit Dergisi. 2013; 19(1): 1-7.

8. Altınbaş A, Yılmaz B, Ekiz F, Aktaş B, Çoban Ş, Başar Ö, ve ark. HBsAg pozitif hastalarda delta hepatit seropozitiflik sıklığı. Cumhuriyet Med J. 2012; 34: 56-9.

9. Yurtsever SG, Er HH, Güngör $S$, Uzun B. Hepatit B virüs enfeksiyonunda delta antikoru sıklığı ve klinik önemi. Viral Hepatit Dergsi. 2011; 17 (2): 69-73.

10. Doğan M, Güneş H, Mete R, Taş T, Mengeloğlu FZ, Küçükbayrak A. Kronik hepatit B infeksiyonlu hastalarda Anti-HDV ve HDAg prevalansı. Dicle Tıp Dergisi. 2013; 40(1): 50-3.

11. Sırmatel F, Yetkin G, Eriş FN, Koruk Tekin S, Duygu F, Karaağaç $L$, ve ark. Sağlıklı kan donörlerinde hepatit $B$ virus, hepatit $C$ virus ve hepatit D virus seroprevalansı. Viral Hepatit Dergisi. 2012; 18(1): 19-22.

12. Azap A, Polat H, Memikoğlu O, Birengel S, Kader Ç, Tekeli E. Hepatit delta virus seroprevalansı: rutin laboratuvar test çalışmalarının önemi. Viral Hepatit Dergisi. 2005; 10(2): 85-9.

13. Tözün N, Özdoğan $O$, Çakaloğlu Y, Idilman R, Karasu Z, Akarca U, Kaymakoğlu S, Ergönül Ö. A Nationwide Prevalence Study and Risk Factors for Hepatitis A, B, C and D Infections in Turkey. The 61st Annual Meeting of the American Association for the Study of Liver Diseases: The Liver Meeting ${ }^{\circledR}$ 2010. October 29 November 22010 ,Boston USA, Poster No: 789 , Hepatology. 2010; 52 :1-697A.
14. Tözün N, Özdoğan $O$, Çakaloğlu $Y$, Idilman R, Karasu $Z$, Akarca $U$, ve ark. Türkiye'de Viral Hepatit A, B, C ve D Enfeksiyonlarının Prevalansı ve Risk Faktörleri. Ulusal Hepatoloji Kongresi 1-5 Haziran 2011,Ankara, Bildiri Özetleri Kitabı http://www.tasl.org. tr/files/file/tasi_Ulusal_Hepatit_sikligi_Calismasi.pdf

15. Demirdal T, Demirtürk N, Aşçı Z. Afyonkarahisar ilinde hepatit delta seroprevalansı. Viral Hepatit Dergisi. 2009; 14: 104-7.

16. Balık I, Onul M, Tekeli E, Caredda F. Epidemiology and clinical outcome of hepatitis D virus infection in Turkey. Eur J Epidemiol. 1991; 7(1): 48-54.

17. Kölgelier S, Demir Aktuğ N, Özçimen S. Adıyaman'da HBsAg pozitif kişilerde delta hepatit seropozitifliği. Viral Hepatit Dergisi. 2012; 19(1): 8-10.

18. Kaya S. Polikliniğimizde izlenen kronik hepatit B virus infeksiyonlu hastalarda anti-HDV sıklığı. Viral Hepatit Dergisi. 2006; 11(3): 154-7.

19. Us T, Akgün Y, Durmaz G, Esengen S. HBV ile enfekte kişilerde Anti-HDV pozitifliği. Viral Hepatit Dergisi. 1999; 2: 76-8.

20. Güdücüoğlu H, Altunbaş S, Bozkurt H, Baykal S, Berktaş M. Van askeri hastanesinde HBsAg pozitif askerlerde delta antikorunun araştırılması. Van Tıp Dergisi. 2006; 13(4): 118-20.

21. Bahcecioglu IH, Aygun C, Gozel N, Poyrazoglu OK, Bulut $Y$, Yalniz M. Prevalence of hepatitis delta virus (HDV) infection in chronic hepatitis B patients in eastern Turkey: still a serious problem to consider. J Viral Hepat. 2011; 18(7): 518-24.

22. Çelen KM, Geyik FM, Uluğ M, Hoşoğlu S. Kronik hepatit B hastalarında anti-HDV sıklığı. Viral Hepatit Dergisi. 2006; 11: 26-9. 